\title{
Soil quality response of reestablished grasslands to mowing and burning
}

\author{
W.H. SCHACHT, J. STUBBENDIECK, T.B. BRAGG, A.J. SMART, AND J.W. DORAN
}

\begin{abstract}
Authors are assistant professor and professor, Department of Agronomy, University of Nebraska-Lincoln, Neb. 685830915; professor, Department of Biology, University of Nebraska-Omaha, Omaha, Neb. 68182-0040; and research technologist, Department of Agronomy at the University of Nebraska-Lincoln; and soil scientist, USDA-ARS and Department of Agronomy, University of Nebraska-Lincoln, Neb.
\end{abstract}

\begin{abstract}
Prescribed burning and mowing are management practices commonly used on grasslands even though there is limited knowledge of long-term effects on soil quality. The influences of mowing and burning on soil quality were determined on 2 reestablished tallgrass sites in eastern Nebraska dominated by silty clay loam soils. Burn treatments included seasonal (i.e., October, May, or July) prescribed burning at either 1-year or 4 year intervals. Mow treatments included seasonal mowing at 4year intervals. Both burn and mow treatments have been imposed at Site 1 since fall 1981. Only the burn treatments have been applied at Site 2 since fall 1979. Soil quality measurements were made at both sites in summer 1994. Season of application of the mow and burn treatments and season $X$ treatment interactions were not significant. Infiltration rates at Site 1 for the mow and annual burn treatments were slower than for the control, whereas infiltration rate was comparable for the 4-year burn treatments and the control. Unlike Site 1, the 1-year and 4-year burn treatments at Site 2 had similar infiltration rates, and the burn treatments had slower infiltration rates than the control. Generally, soil bulk density, pH, electrical conductivity, total nitrogen content, and organic matter content were similar for all treatments. Results demonstrate that repeated burning or mowing treatments can detrimentally impact infiltration rates on silty clay loam sites; however, soil properties other than those measured would need to be studied to explain infiltration response.
\end{abstract}

Key Words: infiltration rate, soil bulk density, soil organic matter content, soil nitrogen content, soil $\mathrm{pH}$.

Prescribed burning is a commonly recommended low-cost method of sustaining the vigor and productivity of warm-season grasslands. Not only does it remove growth-inhibiting litter and invigorate desirable grass species but it also can be used to control undesirable target species (Scifres and Hamilton 1993). Although prescribed burning has been the topic of numerous studies, most prescribed burning research in the Great Plains has dealt with above-ground response (e.g., Owensby and Anderson

Published as journal article 11044, Agriculture Research Division, University of Nebraska.

Manuscript accepted 20 Dec. 1995.
1967, Schacht and Stubbendieck 1985) largely ignoring the longterm effects periodic burning might have on physical and chemical properties of the soil. In the only long-term study conducted in the Great Plains, Owensby and Wyrill (1973) compared soil characteristics of winter- and spring-burn plots to a control at a site in the Kansas Flint Hills. Results indicated that soil chemical properties were affected by frequent burning, but soil bulk density was not altered and water infiltration rate was not measured. Related studies (Vogl and Schorr 1972, Ueckert et al. 1978) conducted in other rangeland types have been short-term and the results have been variable and inconclusive. Most studies, however, suggest that changes in soil chemical and physical properties in response to fire are temporary and return to pre-burn levels within several years post-burn (Ueckert et al. 1978, Scifres and Hamilton 1993).

Mowing treatments are being investigated as alternatives to burning as means of increasing or maintaining the productivity and vigor of warm-season grasses on tallgrass prairic sites (Unpublished data, Bragg and Stubbendieck). Properly-timed mowing treatments may serve as an alternative to burning, or grazing, when vegetation removal is necessary for improvement or maintenance of warm-season grasslands. A limited amount of research has been conducted to quantify vegetation and soil responses to periodic mowing on upland sites of the tallgrass prairie. Research results indicate that periodic mowing has limited effects on species composition (McCarty et al. 1974) or decreases the frequency and vigor of some perennial forbs (Kline 1986). The response of soil properties to mowing, however, was not measured in either study.

As grassland managers become increasingly concerned about the sustainability of management practices, soil response to such management tools as prescribed burning and mowing must be quantified. The objective of this study was to determine the effects of different regimes of prescribed burning and mowing on selected chemical and physical properties of upland soils of seeded warm-season grasslands.

\section{Study Sites}

The study was conducted in eastern Nebraska on 2 upland sites dominated by mixtures of cool- and warm-season grasses. Site 1 is located $52 \mathrm{~km}$ northeast of Lincoln at the Agricultural Research and Development Center, University of Nebraska- 
Lincoln. Average annual precipitation is $760 \mathrm{~mm}$ with $75 \%$ of the precipitation coming as rain during the growing season. Soils of the 4.5-ha study site developed from loess parent material. The dominant soil is Yutan silty clay loam (fine-silty, mixed, mesic Mollic Hapludalfs), with a Tomek silt loam (fine, montmorillonitic mesic Pachic Argiudolls) running through the middle of the site. Both soils are very deep and well drained with moderately slow permeability. The site was seeded in the late 1960 's to a mixture of warm-season grass species, including big bluestem (Andropogon gerardii Vitman), indiangrass [Sorghastum nutans (L.) Nash], switchgrass (Panicum virgatum L.), sideoats grama [Bouteloua curtipendula (Michx.) Torr.], and sand lovegrass [Eragrostis trichoides (Nutt.) Wood]. After establishment, the site was harvested annually for hay through the 1970's. By 1981, the site was still dominated by warm-season grasses, primarily big bluestem, but a cool-season grass, smooth bromegrass (Bromus inermis Leyss.), had become a significant component of the plant community.

In September 1981, the study area was divided into 3 blocks, based on soil and slope. Within each block, 13 0.1-ha plots were randomly allocated to 1 of 13 treatments to evaluate plant and soil response to both periodic mowing and burning. Prescribed burning included 6 treatments: (1) fall burn every fourth year; (2) spring burn every fourth year; (3) summer burn every fourth year; (4) annual fall burn; (5) annual spring burn; and (6) annual summer burn. Mowing included 6 treatments applied every fourth year: (7) fall mow and remove residue; (8) spring mow and remove residue; (9) summer mow and remove residue; (10) fall mow and leave residue; (11) spring mow and leave residue; (12) summer mow and leave residue. No disturbance or removal of plant tissue occurred on the control (13). Each treatment was replicated 3 times in a randomized complete block design. Fall application of treatments occurred shortly after the first killing frost (mid to late October); spring treatments were applied shortly before initiation of warm-season growth (early May); and summer application of treatments took place in mid-July. Three cycles of the 4-year treatments had been completed by the time sampling was conducted in the spring and summer 1994.

Site 2 is located $20 \mathrm{~km}$ northwest of Omaha at the Allwine Prairie Preserve, University of Nebraska-Omaha. Average annual precipitation is $721 \mathrm{~mm}$ with $75 \%$ of the precipitation coming as rain from April through September. The study site was seeded in 1970 to a mix of big bluestem, indiangrass, switchgrass, little bluestem [Schizachyrium scoparium (Michx.) Nash], and sideoats grama on a Marshall silty clay loam with a 7 to $11 \%$ slope (finesilty, mixed, mesic Typic Hapludolls). Marshall silty clay loams form in loess and are found on lower hillsides. They are deep, well drained soils, and permeability is moderate. By 1979, the site was still dominated by warm-season grasses, particularly little bluestem.

\section{Methods}

\section{Infiltration}

Ponded, falling-head infiltration measurements were made using single-ring infiltrometers. Ponded, falling-head infiltration is an effective method for routine measurements and treatment comparisons (Radke and Berry 1993). Three aluminum rings (14.9-cm inside diameter) were randomly positioned in each plot. To measure infiltration, plastic sandwich wrap was formed into a pocket within a ring and an amount of water equivalent to $2.5 \mathrm{~cm}$ was poured into the cavity. At initiation of an infiltration measurement, the plastic wrap was pulled from the ring allowing the water to enter the ring with minimum disturbance to the soil surface. Infiltration was considered complete when there was no free standing water on the soil surface. Two successive measurements of infiltration were made in each ring. The first measurement represented the amount of time required for $2.5 \mathrm{~cm}$ of water within each ring to infiltrate the soil. Immediately following the infiltration of the first $2.5 \mathrm{~cm}$ of water, infiltration time was measured for a second $2.5 \mathrm{~cm}$ of water which represented ponded infiltration. We utilized this "ponding" approach because there were differences in soil water content at different locations within a plot. Natural depressions were common in the plots where water would occasionally accumulate and affect soil moisture and permeability. At Site 1, water infiltration was initially measured in late April 1994. The same sampling procedure was repeated during a second data collection period in late July 1994. Over the 2 sampling periods, infiltration rates were measured at a total of 6 different locations in each plot. Infiltration rate was measured at Site 2 in late July.

\section{Bulk Density}

Soil bulk density was determined at both sites in late July. One soil core (4-cm diameter) was taken to a depth of $7.6 \mathrm{~cm}$ from each ring on the day following measurement of water infiltration. Each core was placed in an airtight container, transported to the laboratory, and bulk density determined (Blake and Hartge 1986).

\section{Chemical Properties}

Twelve vertical, undisturbed soil cores, $1.75 \mathrm{~cm}$ in diameter and $30 \mathrm{~cm}$ in length, were taken from each plot in late April at Site 1 and in late August at Site 2. The cores were taken with a step-down probe and divided into 3 depth increments: $0-7.5,7.5$ 15 , and $15-30 \mathrm{~cm}$. The subsample cores within each plot were composited, oven dried at $100^{\circ} \mathrm{C}$, and ground in a mortar to a fine powder. Samples from each composited increment were used to prepare a 1:1 soil-water mixture with $10 \mathrm{~g}$ of soil and $10 \mathrm{~g}$ of water. Soil reaction of the mixture was determined using a $\mathrm{pH}$ meter. Electrical conductivity $(\mathrm{EC})$ of the same mixture also was measured to give an indication of soil salt levels.

Total soil nitrogen $(N)$ of a subsample was determined for each composited depth interval using a FP-428 nitrogen determinator system 601-700-300 (Leco Corporation, St. Joseph, Mo.) Soil organic matter content of each depth interval also was determined using the Walkley-Black Method (Schulte 1988).

\section{Statistical Analysis}

Data from the 2 sites were analyzed separately. Treatments were compared by analysis of variance procedures for a randomized complete block design with 3 replications. Infiltration rate data at Site 1 were analyzed by analysis of variance in a split-plot design. Sampling date was the main plot and treatment was the subplot. Soil chemical properties at each site were analyzed using a split-plot model. Treatment was the main plot and depth was the subplot. Data analysis of the mow and burn treatments, without the control, indicated that season of implementation of the mow and burn treatments and season $x$ treatment interactions were not significant. Treatment means were subsequently combined by treatment group (i.e., mow, mow/rake, annual burn, and 
Table 1. Means $( \pm$ S.E.) of soil bulk density and time ( $\mathrm{min})$ required for the second $2.5 \mathrm{~cm}$ of water to infiltrate soils by treatment at 2 grassland sites in eastern Nebraska.

\begin{tabular}{|c|c|c|c|c|}
\hline \multirow[b]{2}{*}{ Treatment } & \multicolumn{2}{|c|}{ Site 1} & \multicolumn{2}{|c|}{ Site 2} \\
\hline & $\begin{array}{l}\text { Infiltration } \\
\text { time }\end{array}$ & $\begin{array}{l}\text { Bulk } \\
\text { density }\end{array}$ & $\begin{array}{l}\text { Infiltration } \\
\text { time }\end{array}$ & $\begin{array}{c}\text { Bulk } \\
\text { density }\end{array}$ \\
\hline & $(\min )$ & $\left(\mathrm{Mg} / \mathrm{m}^{3}\right)$ & $(\min )$ & $\left(\mathrm{Mg} / \mathrm{m}^{3}\right)$ \\
\hline Annual bum, fall & $13.3(1.6)$ & $1.10(0.03)$ & $23.9(5.0)$ & $1.28(0.02)$ \\
\hline Annual burn, spring & $12.8(2.1)$ & $1.15(0.04)$ & $25.3(4.8)$ & $1.18(0.05)$ \\
\hline Annual burn, summer & $14.5(2.8)$ & $1.11(0.05)$ & $15.9(3.5)$ & $1.18(0.04)$ \\
\hline 4-year bum, summer & $8.5(2.2)$ & $1.13(0.06)$ & $42.7(9.3)$ & $1.22(0.04)$ \\
\hline Mow, fall & $18.3(4.0)$ & $1.17(0.07)$ & & \\
\hline Mow, spring & $11.6(3.1)$ & $1.04(0.04)$ & & \\
\hline Mow, summer & $11.5(2.5)$ & $1.14(0.05)$ & & \\
\hline Mow/rake, fall & $12.2(2.3)$ & $1.18(0.06)$ & & \\
\hline Mow/rake, spring & $13.3(2.5)$ & $1.08(0.03)$ & & \\
\hline
\end{tabular}

4-year burn) and specific contrasts were used to compare variation in physical and chemical properties of the soils within treatment categories (e.g., control vs. annual burn, mow vs. burn, annual burn vs. 4-year burn). The Statistical Analysis System (SAS 1987) was used for all statistical procedures. Means were considered statistically different at $\mathrm{P}<0.1$.

\section{Results}

\section{Infiltration Results}

Infiltration times for the second $2.5 \mathrm{~cm}$ of water (ponded) varied among treatments at both sites (Table 1). At Site 1, sampling date did not affect infiltration time. Sampling date had a similar effect on infiltration for each of the treatments as the sampling date $X$ treatment interaction was not significant. Infiltration rates at Site 1 for the mowing treatments and annual burning were slower than for the control (Table 2). Burning on a 4-year schedule did not affect infiltration rate when compared to the control. Infiltration rates were more rapid for the 4-year burn than the other burning and mowing treatments. Unlike Site 1 , infiltration rates at Site 2 were slower for the 4-year burn treatment than the control (Table 2). Infiltration rates for the annual burn treatment were also slower than the control and similar to the 4-year burn treatment at Site 2. Infiltration times for the first $2.5 \mathrm{~cm}$ of water were generally 2 to 4 times less than the second $2.5 \mathrm{~cm}$ of water for most treatments at both sites.

\section{Bulk Density}

Soil bulk density differed only between the annual burn and 4 year burn treatments at Site 1 and between the control and annual burn treatments at Site 2 (Table 2). The soil bulk density for the annual burn treatment $\left(1.12 \mathrm{Mg} / \mathrm{m}^{3}\right)$ was higher than for the 4year burn treatment $\left(1.07 \mathrm{Mg} / \mathrm{m}^{3}\right)$ at Site 1 . Bulk density for the soils of the control $\left(1.27 \mathrm{Mg} / \mathrm{m}^{3}\right)$ was higher than the annual burn treatments $\left(1.21 \mathrm{Mg} / \mathrm{m}^{3}\right)$ at Site 2 .

\section{Chemical Properties}

Soil $\mathrm{pH}, \mathrm{EC}$, total $\mathrm{N}$ content, and organic matter content of the top $30 \mathrm{~cm}$ of the soil profile were generally not affected by treatment at either site (Tables 3 and 4). Soil $\mathrm{pH}$ was higher for burn treatments than the mow treatments at Site 1. Depth had a significant effect on all soil properties measured. Soil pH, EC, total N, and organic matter content generally declined from the $0-7.5 \mathrm{~cm}$ interval to the $7.5-15 \mathrm{~cm}$ interval. Soil $\mathrm{pH}, \mathrm{EC}$, and total $\mathrm{N}$ content did not show a further decline with the $15-30 \mathrm{~cm}$ interval. Organic matter content in the $15-30 \mathrm{~cm}$ interval was greater than for the $7.5-15 \mathrm{~cm}$ interval because of the greater volume of soil, but the percentage of organic matter in the 15-30 interval was lower than in the other intervals. Depth had a similar effect on the 4 soil properties for all treatments as the treatment $\times$ depth interactions were not significant.

Table 2. Means for soil quality for 2 grassland sites in eastern Nebraska that were burned or mowed periodically. Specific contrasts made from 12 burn or mow treatments and a control.

\begin{tabular}{|c|c|c|c|c|c|c|c|c|c|}
\hline \multirow{3}{*}{$\frac{\text { Soil quality }}{\text { Infiltration (min) }}$} & \multirow{3}{*}{$\begin{array}{c}\text { Site } \\
1 \\
2\end{array}$} & \multicolumn{7}{|c|}{ Specific contrasts ${ }^{1}$} & \\
\hline & & \multicolumn{2}{|c|}{ Control vs Annual bum } & \multicolumn{2}{|c|}{ Control vs 4-yr burn } & \multicolumn{2}{|c|}{ Control vs $\mathrm{Mow}^{2}$} & \multicolumn{2}{|c|}{ Annual bum vs 4-yr burn } \\
\hline & & $\begin{array}{l}6.9 \\
8.3\end{array}$ & $\begin{array}{l}13.5 \\
21.7\end{array}$ & 8.3 & 27.1 & 6.9 & 13.1 & 13.5 & 7.0 \\
\hline
\end{tabular}

Each pair of means for a soil quality index and site combination is significantly different $(\mathrm{P}<0.1)$.

${ }^{2}$ Includes both mow treatment groups(mow and mow/rake); soil quality indices did not differ between the 2 mow treatment groups. 
Table 3. Mean ( + S.E.) soil pH, electrical conductivity (EC), total nitrogen (N), and total organic matter (OM) in the top $30 \mathrm{~cm}$ of soil at Site 1 .

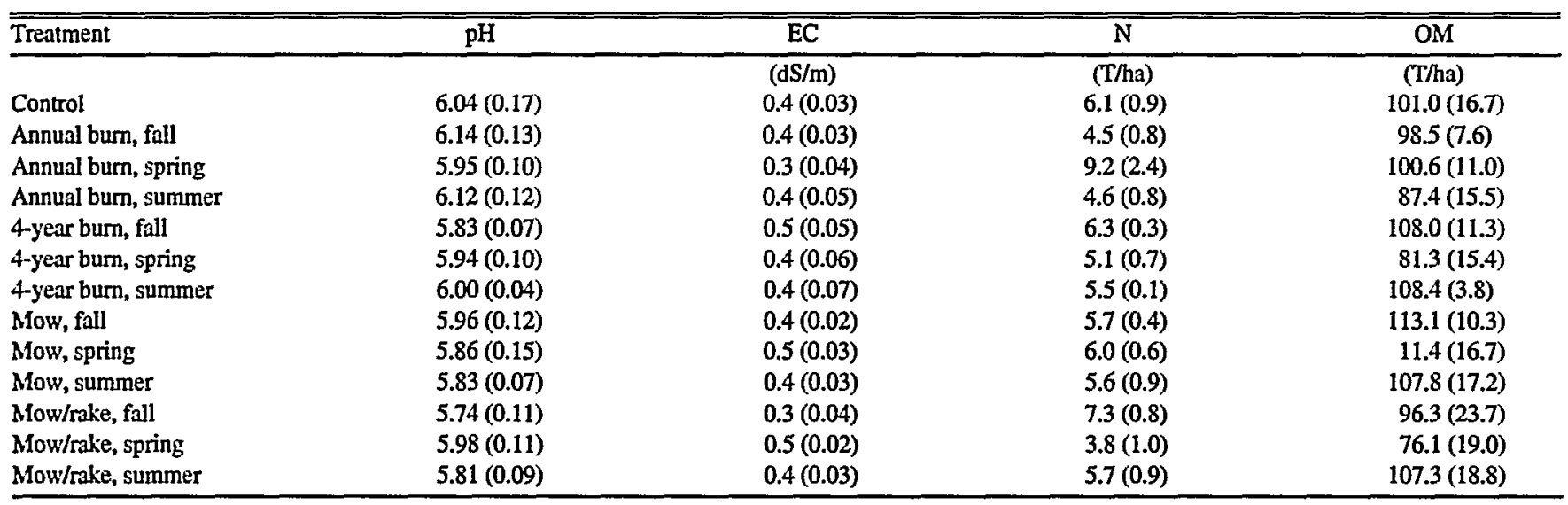

\section{Discussion}

Results of our study indicate that changes in the physical and chemical properties of grassland soils in response to burning are usually either minor or shortlived. Compared to the control, neither annual burning nor burning on a 4-year interval affected the chemical properties measured. There are mixed reports on the effects of prescribed burning on chemical properties of grassland soils. Soil $\mathrm{pH}$ and salt levels usually do not change or are increased only slightly following burning of grasslands (Vogl and Schorr 1972, Ueckert et al. 1978), and changes induced by burning are generally temporary (Scifres and Hamilton1993). Basicity is potentially promoted by reduction in organic acids and the increase in bases after release of salts of calcium, potassium, magnesium, and sodium. Burning is also often reported to decrease total soil $\mathrm{N}$ because of $\mathrm{N}$ volatilization during the fire and accelerated use of $\mathrm{N}$ by soil microorganisms and higher plant life-forms after the fire (Heady 1975, Vallentine 1989). Results of other studies (Aldous 1934, Ehrenreich and Aikman 1963, Nimir and Payne 1978), however, show no $\mathrm{N}$ response to burning. Annual burns have been shown to reduce humus content of surface soil by preventing mulch accumulation (Anderson 1965). Time for the surface mulch load to be replaced is variable but it appears that 2 to 15 years are required, depending on precipitation, plant community, and harvesting (Blaisdell 1953, McAtee et al. 1979). Even annual removal of aboveground plant biomass by fire did not affect organic matter content of the soils in our study, indicating that origin of most of the soil organic matter was roots.

On Site 1 , water infiltration was negatively impacted by annual burning but burning on a less frequent basis, a 4-year interval, did not affect infiltration rates (Table 2). These results are similar to the findings of a shorter-term study in western Texas (Ueckert et al. 1978) in which most fire effects were minimal and return of the soil properties to control levels occurred within 3 to 5 years after burning.

Annual consumption of litter by fire leaves the soil surface relatively bare and removes a significant amount of organic matter that might otherwise be incorporated into the soil. Organic matter plays a critical role in the formation and stabilization of soil aggregates which provide for the pore space favorable for rapid water infiltration. In our study, however, soil surface litter did not directly impact our estimations of infiltration rates, because when litter was present (e.g., on the control plots), we removed most of the litter from the sample area before ring placement and infiltration measurement. Furthermore, organic matter content of the soil on the annual burn plots was equal to that of the control plots, indicating that annual removal of most of the aboveground plant tissue did not affect soil organic matter content. Soil bulk density was also similar between the control and burn treatments. The slow infiltration rates of the annual burn plots may have been related to a surface condition that we were not able to detect or measure. Observations (Hanks and Anderson 1957, McMurphy and Anderson 1965) of frequently-burned rangeland in the Kansas Flint Hills indicated annual burning reduced infiltration rates. Similar to our results, Owensby and Wyrill (1973) reported that soil bulk densities of burned and control sites were comparable. They proposed that some physical changes occurred during burning, but the changes were so slight that they could not be detected by the bulk density measurements used. Infiltration rate differences could be related to the effect of fire on noncapillary porosity of the uppermost portion of the soil profile (Ueckert et

Table 4. Mean ( $(S . E$.) soil pH, electrical conductivity (EC), total nitrogen (N), and total organic matter (OM) in the top $30 \mathrm{~cm}$ of soil at Site 2 .

\begin{tabular}{|c|c|c|c|c|}
\hline Treatment & $\mathrm{pH}$ & $\mathrm{EC}$ & $\mathbf{N}$ & $\mathrm{OM}$ \\
\hline & & $(\mathrm{dS} / \mathrm{m})$ & (T/ha) & (T/ha) \\
\hline Control & $5.60(.18)$ & $.27(.05)$ & $3.99(.39)$ & $101.6(8.2)$ \\
\hline Annual burn, fall & $5.48(.20)$ & $.33(.07)$ & $3.74(.62)$ & $96.5(12)$. \\
\hline Annual burn, spring & $5.65(.20)$ & $.31(.15)$ & $5.31(.24)$ & $116.3(6.6)$ \\
\hline Annual bum, summer & $5.66(.15)$ & $.30(.12)$ & $4.42(.59)$ & $103.6(7.0)$ \\
\hline 4-year bum, fall & $5.53(.13)$ & $.32(.08)$ & $4.89(.73)$ & $110.7(11.8)$ \\
\hline 4-year burn, spring & $5.49(.22)$ & $.41(.12)$ & $5.53(.25)$ & $109.9(5.0)$ \\
\hline 4-year burn, summer & $5.46(.11)$ & $.34(.10)$ & $3.47(.38)$ & $94.3(7.7)$ \\
\hline
\end{tabular}


Table 5. Mean canopy cover (\%) ( $(\mathrm{SSE})$ of the major plant species by treatment in 1994 at 2 grassland sites in eastern Nebraska. ${ }^{1}$

\begin{tabular}{|c|c|c|c|c|c|c|c|c|}
\hline \multirow[b]{2}{*}{ Treatment } & \multicolumn{4}{|c|}{ Site 1 } & \multicolumn{4}{|c|}{ Site 2 } \\
\hline & $\underset{\text { bluestem }}{\text { Big }}$ & $\begin{array}{c}\text { Sideoat } \\
\text { grama }\end{array}$ & $\begin{array}{c}\text { Smooth } \\
\text { brome }\end{array}$ & $\begin{array}{l}\text { Kentucky } \\
\text { bluegrass }\end{array}$ & $\begin{array}{c}\text { Big } \\
\text { bluestem }\end{array}$ & $\begin{array}{c}\text { Little } \\
\text { bluestem }\end{array}$ & $\begin{array}{c}\text { Carex } \\
\text { spp. }\end{array}$ & $\begin{array}{l}\text { Kentucky } \\
\text { bluegrass }\end{array}$ \\
\hline \multicolumn{9}{|c|}{ 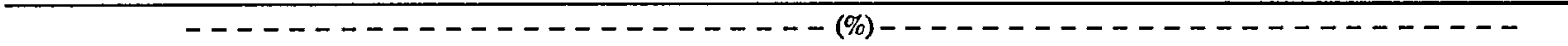 } \\
\hline Control & $59 \pm 2.9$ & $17 \pm 2.7$ & $60 \pm 3.3$ & $46 \pm 1.3$ & $84 \pm 1.1$ & $7 \pm 2.4$ & $12 . \pm 3.0$ & $41 \pm 6.1$ \\
\hline Annual bum, fall & $88 \pm 1.5$ & $10 \pm 1.7$ & $38 \pm 3.3$ & $6 \pm 1.8$ & $58 \pm 1.4$ & $51 \pm 1.7$ & $21 \pm 0.6$ & $3 \pm 1.2$ \\
\hline Annual burn, spring & $77 \pm 2.3$ & $2 \pm 0.8$ & $28 \pm 4.0$ & $1 \pm 0.6$ & $61 \pm 2.0$ & $62 \pm 2.1$ & $10 \pm 1.5$ & 0 \\
\hline Annual burn, summer & $76 \pm 2.0$ & $2 \pm 1.2$ & $24 \pm 2.4$ & $2 \pm 0.1$ & $39 \pm 2.3$ & $64 \pm 1.1$ & $15 \pm 1.0$ & 0 \\
\hline 4-year burn, fall & $68 \pm 1.4$ & $6 \pm 1.6$ & $69 \pm 1.6$ & $20 \pm 1.3$ & $63 \pm 3.2$ & $29 \pm 2.8$ & $20 \pm 1.7$ & $46 \pm 3.3$ \\
\hline 4-year bum, spring & $46 \pm 2.4$ & $11 \pm 2.0$ & $55 \pm 4.0$ & $16 \pm 1.8$ & $61 \pm 2.3$ & $50 \pm 2.1$ & $28 \pm 0.9$ & $8 \pm 2.0$ \\
\hline 4-year burn, summer & $48 \pm 2.2$ & $5 \pm 1.3$ & $84 \pm 0.6$ & $20 \pm 1.6$ & $79 \pm 1.4$ & $16 \pm 1.7$ & $31 \pm 1.6$ & $27 \pm 2.3$ \\
\hline Mow, fall & $57 \pm 2.9$ & $11 \pm 2.4$ & $44 \pm 3.8$ & $24 \pm 2.6$ & & & & \\
\hline Mow, spring & $81 \pm 1.9$ & $18 \pm 2.9$ & $46 \pm 2.9$ & $46 \pm 2.3$ & & & & \\
\hline Mow, summer & $48 \pm 2.4$ & $25 \pm 3.3$ & $60 \pm 4.2$ & $60 \pm 3.5$ & & & & \\
\hline Mow/rake, fall & $47 \pm 1.5$ & $28 \sqrt{3.3}$ & $55 \pm 4.0$ & $28 \pm 2.9$ & & & & \\
\hline Mow/rake, spring & $62 \pm 5.0$ & $16 \pm 2.1$ & $41 \pm 3.7$ & $33 \pm 2.1$ & & & & \\
\hline Mow/rake, summer & $70 \pm 2.9$ & $27 \pm 3.6$ & $43 \pm 3.5$ & $44 \pm 3.6$ & & & & \\
\hline
\end{tabular}

Total canopy cover by treatment exceeds $100 \%$ because of canopy overlap.

al. 1978), crumb structure or aggregate size at the soil surface (Owensby and Wyrill 1973, Ueckert et al. 1978), or the development of water-repellent soil surfaces from hydrophobic compounds of plant residue (DeBanco et al. 1976, Scifres and Hamilton 1993). Other factors reported to affect infiltration rates, such as frost action and soil biological activity (Achouri and Gifford 1984, Tricker 1981), are seasonal and their level of activity are assumed to have been comparable on all plots.

Data from Site 1 indicate that burning at a 4-year frequency does not affect soil quality to the point of negatively impacting water infiltration. At Site 2, however, infiltration rates were slower than the control for both the annual burn and 4-year burn treatments (Table 2). None of the other soil quality properties measured would indicate why infiltration was relatively slow for the 4-year burned plots. Although the soils at the 2 sites are similar, Site 2 is located on terraces which were constructed prior to seeding. Terracing can result in localized removal of topsoil and exposure of subsoils which could partially explain the high variability in mean estimates at Site 2 and the relatively high infiltration times and soil bulk densities measured at Site 2 in comparison to Site 1.

There was no clear pattern relating canopy cover of the major plant species (Table 5) (unpublished data, Bragg and Stubbendieck) to infiltration rates, or any other soil property measured. Annual burning appears to have a negative effect on the canopy cover of cool-season grasses, regardless of the season of

Table 6. Average rainfall intensity and duration patterns for event return periods of 1 to 100 years for the 2 study sites in eastern Nebraska (Hershfield (1961).

\begin{tabular}{|c|c|c|c|}
\hline \multirow[b]{2}{*}{ Relum period } & \multicolumn{3}{|c|}{ Rainfall durations (minutes) } \\
\hline & 30 & 60 & 120 \\
\hline & \multicolumn{3}{|c|}{$--------(\mathrm{cm})-\cdots-\cdots--$} \\
\hline 1 & 2.64 & 3.43 & 3.91 \\
\hline 2 & 3.25 & 4.11 & 4.59 \\
\hline 5 & 4.24 & 5.25 & 6.19 \\
\hline 10 & 4.92 & 6.29 & 7.23 \\
\hline 25 & 5.79 & 7.28 & 8.40 \\
\hline 50 & 6.12 & 8.20 & 9.49 \\
\hline 100 & 7.11 & 9.22 & 10.54 \\
\hline
\end{tabular}

application. Most plots in the other treatments, however, had similar mixtures of plant species at the time of soil sampling at both sites. It does not appear that the minimal differences in species composition of plant communities on the different plots could affect soil quality.

Mowing treatments reduced infiltration rate compared to the control at Site 1 (Table 2), but the treatments did not affect the other soil properties measured. Infiltration rates and soil organic matter content were similar for the 2 groups of mow treatments (mow vs. mow/rake treatments) indicating that periodic removal of aboveground plant material on the mow/rake treatments was not a major cause of reduced infiltration rates relative to the control. This conclusion agrees with the discussion in the burning section. Bulk density was not affected by the mowing treatments indicating that machinery used in the mowing and (or) raking processes did not cause sufficient soil compaction to increase bulk density. Similar to frequent burning, periodic mowing apparently affects the soil surface, or a related soil property, in such a way to impede water infiltration.

Even though infiltration rates of the silty clay loam soils of our study sites were affected by the management practices, the intensity of rainfall events on the study areas infrequently exceed the capacity of the burn or mow plots to absorb water (Table 6). For the burn and mow plots, the summation of the infiltration times for the first and second $2.5 \mathrm{~cm}$ of water was about 30 minutes or less in all but 1 case. Long-term averages for the 2 sites show that rainfall events approaching $5 \mathrm{~cm}$ in 30 minutes occur only once every 10 to 25 years (Table 6); therefore, the increased infiltration times measured on the burn and mow plots probably do not represent an environmental hazard. Our observations support this conclusion as there were no signs of erosion or sediment movement on the plots at the 2 sites. Furthermore, results of other studies (Emmerich and Cox 1992, Simanton et al. 1991) demonstrated that surface runoff and sediment production on grasslands was not affected by burning or clipping treatments. The decline in infiltration time caused by burning or mowing, however, may be greater on other sites with different soils, steeper slopes, or different soil surface conditions. In some cases the resulting infiltration rates could be exceeded by rainfall intensity resulting in runoff and sediment production. Future research should be designed to determine the effect of burning on infiltration-related properties 
of the upper levels of the soil profile, such as aggregation and macroporosity. Grasslands could be more effectively managed with a better understanding of how management practices and soil properties interact to affect water infiltration.

\section{Literature Cited}

Achouri, M. and G.F. Gifford. 1984. Spatial and seasonal variability of field measured infiltration rates on a rangeland site in Utah. J. Range Manage. 37:451-455.

Aldous, A.E. 1934. Effect of burning on Kansas bluestem pastures. Kansas Agr. Exp. Sta. Tech. Bull. 38.

Anderson, K.L. 1965. Time of burning as it affects soil moisture in an ordinary upland bluestem prairie in the Flint Hills. J. Range Management. 18:311-316.

Blaisdell, J.P. 1953. Ecological effects of planned burning on sagebrushgrass range on the upper Snake River Plains. USDA Tech. Bull. 1075.

Blake, G.R. and K.H. Hartge. 1986. Bulk density. p. 363-375. In: A. Klute (ed.), Methods of soil analysis. Part 1. 2nd ed. Agron. Monogr. 9. ASA and SSSA, Madison, Wisc.

DeBano, L.F., S.M. Savage, and D.M. Hamilton. 1976. The transfer of heat and hydrophobic substances during burning. Soil Sci. Soc. Amer. 40:779-782.

Ehrenreich, J.H. and J.M. Aikman. 1963. An ecological study of the effect of certain management practices on native prairie in Iowa. Ecol. Monogr. 33:113-130.

Emmerich, W.E. and J.R. Cox. 1992. Hydrologic characteristics immediately after seasonal burning on introduced and native grasslands. J. Range Manage. 45:476-479.

Hanks, R.J. and K.L. Anderson. 1957. Pasture burning and moisture conservation. J. Soil and Water Conserv. 12:228-229.

Heady, H.F. 1975. Rangeland management. McGraw-Hill, N.Y.

Fersfield, D.M. 1961. Rainfall frequency atlas of the United States. Commerce Dept. Tech. Paper No. 40., U.S. Government Printing Office, Washington, D.C.

Kline, V.M. 1986. Response of sweet clover (Melilotus alba Desr.) and associated prairie vegetation to seven experimental burning mowing treatments. p. 149-152. In: G.K. Clambey and R.H. Pemble (eds.), Proc. 9th North American Prairie Conf. Tri-College University Center for Environmental Studies, Fargo, N.D.
McAtee, J.W., C.J. Scifres, and D.L. Drawe. 1979. Improvement of gulf cordgrass range with burning or shredding. J. Range Manage. 32:372-375.

McCarty, M.K., D.L. Klingman, and L.A. Morrow. 1974. Interrelations of weed control and pasture-management methods at Lincoln, Nebr. 1949-1969. USDA Tech. Bull. 1473. Washington, D.C.

McMurphy, W.E. and K.L. Anderson. 1965. Burning Flint Hills range. J. Range Manage. 18:265-269.

Nimir, M.B. and G.F. Payne. 1978. Effects of spring burning a mountain range. J. Range Manage. 31:259-263.

Owensby, C.E. and K.L. Anderson. 1967. Yield response to time of burning in the Kansas Flint Hills. J. Range Manage. 20:12-16.

Owensby, C.E. and J.B. Wyrill III. 1973. Effects of range burning on Kansas Flint Hills soil. J. Range Manage. 26:185-188.

Radke, J.K. and E.C. Berry. 1993. Infiltration as a tool for detecting soil changes due to cropping, tillage, and grazing livestock. Amer. J. Alternative Agr. 8:164-174.

SAS Institute, Inc. 1987. User's guide: Statistics. SAS Institute, Cary, N.C.

Schacht, W.H. and J. Stubbendieck. 1985. Prescribed burning in the Loess Hills mixed prairie of southern Nebraska. J. Range Manage. 38:47-51.

Scifres, C.J. and W.T. Hamilton. 1993. Prescribed burning for brushland management. Texas A\&M Univ. Press, College Station, Tex.

Schulte, E.E. 1988. Recommended soil organic matter tests. In: W.C. Dahnke (ed.), Recommended chemical soil test procedures for the North Central Region. North Central Regional Pub. No. 221, North Dakota State University, Fargo, N.D.

Simanton, J.R., M.A. Weltz, and H.D. Larsen. 1991. Rangeland experiments to parameterize the water erosion prediction project model vegetation canopy cover effects. J. Range Manage. 44:276-282.

Tricker, A.S. 1981. Spatial and temporal patterns of infiltration. J. Hydrol. 49:261-277.

Ueckert, D.N., T.L. Whigham, and B.M. Spears. 1978. Effect of burning on infiltration, sediment, and other soil properties in a mesquitetobosa-grass community. J. Range Manage. 31:420-425.

Vallentine, J.F. 1989. Range development and improvements. Brigham Young Univ. Press, Provo, Ut.

Vogl, R.J. and P.K. Schorr. 1972. Fire and manzanita chaparral in the San Jacinto Mountains, Cal. Ecology 53:1179. 